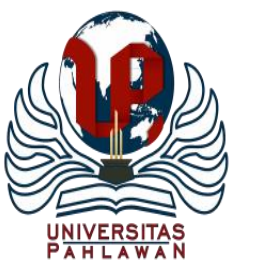

Jurnal Basicedu Volume 4 Nomor 3 Tahun 2020 Halm. 696 - 706

JURNAL BASICEDU

Research \& Learning in Elementary Education

https://jbasic.org/index.php/basicedu/index

\title{
Penerapan Pembelajaran Kooperatif Picture And Picture Bermedia Mind Map Untuk Meningkatkan Kemampuan Literasi Sosial Pada Peserta Didik Sekolah Dasar
}

\author{
Suryadin Hasyda ${ }^{1}$, Arifin Djenawa ${ }^{2}$ \\ Pendidikan Guru Sekolah Dasar, Universitas Muhammadiyah Kupang \\ E-mail : suryadinhasyda92@gmail.com ${ }^{1}$, adjenawa@gmail.com ${ }^{2}$
}

\begin{abstract}
Abstrak:
Kegiatan penelitian ini menggambarkan peningkatan kecakapan literasi sosial peserta didik melalui model pembelajaran kooperatif picture and picture pada peserta didik kelas IV SDN Ende 1. Jenis penelitian PTK, dengan desain mengikuti model Mc Taggart dan Kemmis. Hasil analisis menunjukan model pembelajaran kooperatif picture and picture mampu meningkatkan aktivitas dan kemampuan literasi sosial peserta didik, dibuktikan dengan hasil pengamatan siswa pada tahap 1 berjumlah $68 \%$ masuk kedalam kriteria valid, sedangkan skor kelas hasil pengamatan siswa pada tahap II berjumlah $88 \%$ kriteria sangat valid. Hasil tes tahap I siswa mencapai skor 60 pada kategori valid, sedangkan hasil tes pada tahap II siswa mencapai skor $86,55 \%$ masuk dalam kategori sangat valid. Simpulan yang dihasilkan pada penelitian adalah dengan menerapkan pembelajaran kooperatif picture and picture memberikan akibat positif terhadap kemampuan literasi sosial anak didik yang ditunjukkan pada peningakatan keberhasilan tes hasil belajar pada siklus II.

Kata kunci: kooperatif picture and picture, mind map, literasi sosial
\end{abstract}

\begin{abstract}
:
This research activity illustrates the improvement of students' social literacy skills through the picture and picture cooperative learning model in grade IV students of SDN Ende 1. PTK research type, with the design following the Mc Taggart and Kemmis models. The results of the analysis show the picture and picture cooperative learning model can improve the activities and social literacy skills of students, as evidenced by the observations of students in stage 1 amounting to $68 \%$ into valid criteria, while the class scores of student observations in stage II amounting to $88 \%$ are very valid criteria. The results of the Phase I test of students reached a score of 60 in the valid category, while the results of the test in Phase II of the students reached a score of $86.55 \%$ included in the very valid category. The conclusions generated in the study are by applying picture and picture cooperative learning to have a positive effect on the social literacy abilities of students shown in the improvement of the success of the learning outcomes test in the second cycle.
\end{abstract}

Keywords: cooperative picture and picture, mind map, social literacy

Copyright (c) 2020 Suryadin Hasyda, Arifin Djenawa

Corresponding author :

Address : Jln. KH.Ahmad Dahlan, No.17, Kota Kupang

Email : suryadinhasyda92@gmail.com

ISSN 2580-3735 (Media Cetak)

Phone : 081237981810

ISSN 2580-1147 (Media Online)

DOI: 10.31004/basicedu.v4i3.414 


\section{PENDAHULUAN}

Pendidikan merupakan kegiatan meningkatkan, menjaga, dan mengembangkan pengetahuan manusia menjadi berkualitas sesuai kebutuhan zaman. Peran pendidikan sangat penting dalam meningkatkan kualitas SDM. UU RI No 20 tahun 2003 "pendidikan dilaksanakan agar mendapatkan tujuan yang diinginkan bersama yakni berfungsi mengembangkan keterampilan dan membentuk watak serta peradaban bangsa yang bermartabat dalam rangka mencerdaskan kehidupan bangsa, dan bertujuan untuk berkembangnya potensi peserta didik agar menjadi manusia yang beriman dan bertakwa kepada Tuhan Yang Maha Esa, berakhlak mulia, sehat, berilmu, cakap, kreatif, mandiri, dan menjadi warga negara yang demokratis serta bertanggung jawab.”

Awal tahun 2016, pemerintah mensosialisasikan gerakan bernama gerakan literasi sekolah (GLS). Gerakan tersebut melibatkan semua (stakeholder) di lingkungan sekolah. Gerakan ini didukung oleh PERMENDIKBUD No 23 tahun 2015 berkaitan Perkembangan Budi Pekerti, yang mencakup kegiatan meningkatkan minat anak pada membaca. Literasi tidak hanya merujuk pada rana kebahasaan saja, tetapi pemahaman literasi telah bertransformasi luas pada disiplin-disiplin ilmu yang lain.

Gerakan literasi memperkuat proses pendidikan yang sudah ada sebagaimana tertera dalam PERMEN No. 65 tahun 2013 standar proses pendidikan SD dan SMP. Berdasarkan tujuan gerakan literasi, maka standar proses yang dimaksud dalam peraturan di atas mengandung maksud memberdayakan literasi melalui proses pembelajaran. Untuk itu sangatlah penting membenahi beberapa faktor esensial yang menunjang kesuksesan pembelajaran itu sendiri. Salah satu faktor yang selalu mendapat perhatian publik adalah kualitas guru sebagai salah satu pilar penopang pendidikan. Guru memiliki kedudukan dan peran penting dalam mencapai visi pendidikan nasional. Guru dipandang sebagai figur pendidik yang menyatu dengan perubahan. Penyatuan dan perubahan berarti mendorong guru menciptakan proses pendidikan yang beradaptasi dengan perubahan secara nasional dan global.

Dalam kegiatan belajar mengajar pendidik bisa sebagai perencanaan (planer) atau desainer (designer) pelajaran, sebagai implementasi atau keduanya (Sanjaya, 2006). Hal ini memotivasi guru untuk membiasakan diri pada kegiatan yang bersifat inovatif dan konstruktif bersama siswa. Secara eksplisit kita sering mendengar bahwa pembelajaran harus bersifat konstruktif, dalam artian membangun kompetensi dan potensi peserta didik. Oleh sebab itu, guru tidak hanya membatasi diri sebagai peran pemberi pengetahuan saja, tetapi juga mendorong pertumbuhan potensi diri peserta didik yang sejalan dengan penanaman pengetahuan. Untuk itu asumsi yang memposisikan diri sebagai pusat pengetahuan perlu ditinggalkan, dan berupaya membangun proses pendidikan yang kolaboratif dan dialogis dimana peserta didik menjadi pusat pembelajaran. 
Mengajar merupakan aksi mengkompilasi berbagai kompetensi yang selalu menjadi bagian dari figur guru sebagai pendidik. Ada empat kompetensi dasar yakni pedagogik, profesional, sosial dan kepribadian (Darmastuti, 2014). Untuk itu, dalam pembelajaran guru mendorong dan memotivasi dirinya untuk mampu memperlihatkan keempat kompetensi ini sebagai bagian dari aktivitas belajar bersama peserta didik. Hal-hal yang berkaitan dengan mengelola dan melakukan penyampaian materi pembelajaran selalu menjadi fokus seorang guru. Pengelolaan yang baik dengan suasana interaksi yang dinamis antara siswa dengan guru akan memberikan ekspetasi positif terhadap pembelajaran yang bermakna.

Kegiatan pembelajaran bermakna memerlukan sebuah desain dan strategi pembelajaran yang baik dari seorang guru. Guru menyiapkan diri, baik mental maupun fisik untuk belajar bersama siswanya. Strategi pembelajaran yang dipakai seorang guru di kelas bertujuan untuk menjadikan semua peserta didik menjadi pebelajar yang mandiri selama hidupnya. Peserta didik akan menjadi komponen penting untuk mewujudkan sebuah masyarakat belajar (learning community). Berkeanan dengan hal tersebut, maka pembelajaran subjek tertentu membutuhkan persiapan yang efektif.

IPS merupakan subjek pembelajaran di level SD. Dalam konteks pendidikan dasar tersebut, eksistensi pendidikan IPS berkaitan berbagai disiplin ilmu pengetahuan sosial. Pembelajaran IPS mencari tahu kejadian, kenyataan, konsep yang berhubungan dengan isu sosial. (Gunawan, 2011) menjelaskan tujuan pembelajaran IPS untuk menumbuhkan cara berpikir peserta, meningkatkan pengetahuan, pemahaman dan kemampuan meng.analisis terhadap keadaan sosial masyarakat dalam rangka tumbuhnya warga negara yang baik. Dengan kata lain mengembangkan kemampuan anak untuk menjadi seorang yang berahlak, sehat, berilmu, cakap, kreatif, mandiri dan menjadi warga negara yang demokrasi serta bertanggung jawab. Tujuan yang luas pula mengharapkan murid menjadi pribadi yang mempunyai kema.mpuan literasi sosial. Kemampuan literasi disini mengarah pada melek aksara/huruf, melek visual, serta kemampuan memecahkan masalah yang dihadapi dalam lingkungan masyarakatnya dengan menggunakan skill dan potensi dirinya. Kemampuan lain yang ditingkatkan dan harus terealisasi dalam kegiatan belajar dapat berupa kejujuran.

Melihat cakupan tujuan IPS di sekolah dasar tersebut, maka penting bagi seorang guru menyiapkan desain pembelajaran yang tepat sesuai kebutuhan siswa. Proses pengembangannya pendidik mempunyai peran dalam mengelola suasana belajar yang aman dan tertib. Untuk itu guru perlu memiliki motivasi dalam menjalankan tugas sesuai dengan aturan guru profesional. Penerapan strategi pembelajaran dalam IPS tentu saja berorientasi pada siswa itu sendiri untuk membangun kemandirian dan kematangan pada empat aspek, yakni sikap religius, sikap sosial, pengetahuan dan keterampilan. 
Pembelajaran IPS bersifat partisipatoris, artinya dalam pelaksanaan pembelajaran interaksi antara pengajar dan siswa berjalan intens. Guru menciptakan iklim belajar yang nyaman dan menyenangkan, dan hal ini dilakukan dengan menerapkan strategi belajar yang sesuai dengan intisari materi serta mudah beradaptasi dengan karakteristik peserta didik dan kondisi sosial. Selain itu, penerapan strategi belajar membutuhkan keefektifan dalam pemilihan media yang baik. Guru harus mampu menunujukan kemampuannya dalam mengelolah dan menggunakan strategi pembelajaran. Sejalan dengan pendapat Glasser (dalam (Rusman, 2012)) yakni kompetensi guru berhubungan 4 hal yang dikuasai seorang pengajar, yakni menguasai bahan ajar, menilai perilaku siswa, melaksanakan kegiatan belajar, dan mengevaluasi hasil belajar peserta.

Secara faktual, kebanyakan guru menerapkan strategi pembelajaran IPS tanpa memahami esensi materi dan memperhatikan karakteristik siswa. Masih banyak guru menerapkan strategi yang menempatkan dirinya sebagai sentral, sumber pengetahuan dan mengabaikan sumber-sumber belajar lain seperti perpustakaan sekolah, media elektronik, dan kehidupan sosial masyarakat sekitar. Fenomena ini tentu kontradiktif dengan semangat gerakan literasi yang pada hakikatnya sarana bagi peserta dalam mengenal, mem.ahami, dan aplikasikan ilmu yang didapatkannya.

Permasalahan tersebut juga terjadi di SDN Ende 1 yang berada di Kelurahan Kota Ratu, Kabupaten Ende, provinsi Nusa Tenggara Timur.
Peneliti mengadakan observasi dan menemukan beberapa hal yang membutuhkan perbaikan. Pertama, siswa menjadi pembelajar pasif, hanya mendengar apa yang disampaikan guru dan siswa tidak dimotivasi untuk melakukan aktivitas saat proses belajar mengajar. Kedua, guru tidak memanfaatkan sumber bacaan lain sebagai bahan komplementer materi pelajaran. Ketiga, sekolah belum memiliki program pengembangan literasi yang sistematis untuk menumbuhkan budaya bacatulis, misalnya menetapkan jam kunjung perpustakaan bagi setiap kelas.

Berdasarkan permasalahan yang terjadi di Sekolah Dasar Negeri Ende 1, diharapkan seorang guru memilih model dan strategi yang tepat untuk menciptakan pembelajaran yang efektif. Bersamaan dengan penerapan strategi, guru juga perlu menetapkan media pembelajaran. Pembelajaran kooperatif sangat baik diterapkan di sekolah dasar. Dalam proses belajar kooperatif peserta didik dibentuk kedalam kelompok kecil secara heterogen untuk menyelesaikan materi yang disampaikan guru (Huda, 2011).

Model kooperatif yang memiliki karakteristik kusus adalah pictuter and picture. Model picture and picture dalam IPS mengandalkan gambar realita sosial sebagai media instruksional. Pemanfaatan gambar disini tidak bersifat mandiri, tetapi disertai ilustrasi bacaan yang membantu peserta didik menemukan pokok-pokok pikiran materi pelajaran. Kegiatan pembelajaran picture and picture menggunakan rangkaian gambar dan dipasangkan menjadi urutan yang logis. Ada 
beberapa keunggulan jika guru menerapkan picture and picture antara lain: (1) guru bisa dengan mudah mengetahui kemampuan masing-masing peserta didik, (2) melatih siswa untuk berpikir logis dan sistematis, (3) peserta didik belajar untuk berpikir menurut sudut pandangnya sendiri sekaligus melatih diri untuk berargumentasi terhadap suatu prespektif gambar, dan (4) menumbuhkan motivasi belajar peserta didik (Suprijono, 2009).

Memahami pesan gambar memerlukan ide atau pikiran yang mendeskripsikan keadaan gambar tersebut. Pikiran tersebut dituangkan dalam media yang dapat menjembatani objek belajar dengan peserta didik sebagai pembelajar. Penggunaan media mind map merupakan salah satu alternatif dalam pembelajaran IPS dalam merangkai pesanpesan gambar. Dengan menggunakan mind map peserta didik menentukan sebuah kata kunci sebagai ide sentral. Kemudian kata kunci tersebut dikembangkan secara luas menurut jalan pikiran peserta didik (Devi et al., 2015). Dengan cara seperti ini mind map menyimpan ilmu dan mengambil ilmu secara sistematis. Penerapan mind map dalam pembelajaran kooperatif sangat relevan, sebagaimana pernyataan teori elaborasi kognitif yang menggambarkan penelitian psikologo kognitif bahwa jika informasi ingin dipertahankan didalam memori dan berhubungan dengan informasi yang sudah ada didalam memori orang yang belajar harus terlihat dalam semacam pengaturan kembali kognitif, atau elaborasi dari materi (Slavin, 2005).

Berdasarkan kajian konseptual dan kenyataan pada latar belakang maka perlu dilaksanakan penelitian dengan judul "Penerapan Pembelajaran Kooperatif Picture and Picture Bermedia Mind Map untuk Meningkatkan Kemampuan Literasi Sosial Pada Peserta Didik Kelas IV di Sekolah Dasar".

\section{METODE}

Jenis penelitian ini yakni penelitian tindakan kelas (classroom action research). PTK adalah suatu bentuk penelitian yang bersifat reflektif dengan melaksanakan tindakan untuk memperbaiki proses pembelajaran sehingga dapat meningkatkan hasil belajar siswa. (Ananda et al., 2015) mengatakan bahwa fungsi PTK sebenarnya sebagai "sarana dalam meningkatkan kualitas dan efisiensi kegiatan pendidikan."

Rancangan atau desain PTK ini menggunakan model Kemmis dan Taggart, yaitu berbentuk spiral, dimana alur penelitian berupa planning (perencanaan), action (tindakan), observation (pengamatan), dan reflection (refleksi) (Ananda et al., 2015). Langkah pada siklus berikutnya adalah perencanaan yang sudah direvisi, tindakan, pengamatan, dan refleksi. Sebelum masuk pada siklus I diadakan tindakan pendahuluan yang berupa identifikasi permasalahan. Siklus pada spiral dari tahap-tahap penelitian tindakan kelas dapat dilihat pada gambar berikutnya: 
701 Penerapan Pembelajaran Kooperatif Picture And Picture Bermedia Mind Map Untuk Meningkatkan Kemampuan Literasi Sosial Pada Peserta Didik Kelas IV di Sekolah Dasar - Suryadin Hasyda, Arifin Djenawa

DOI: $10.31004 /$ basicedu.v4i3.414

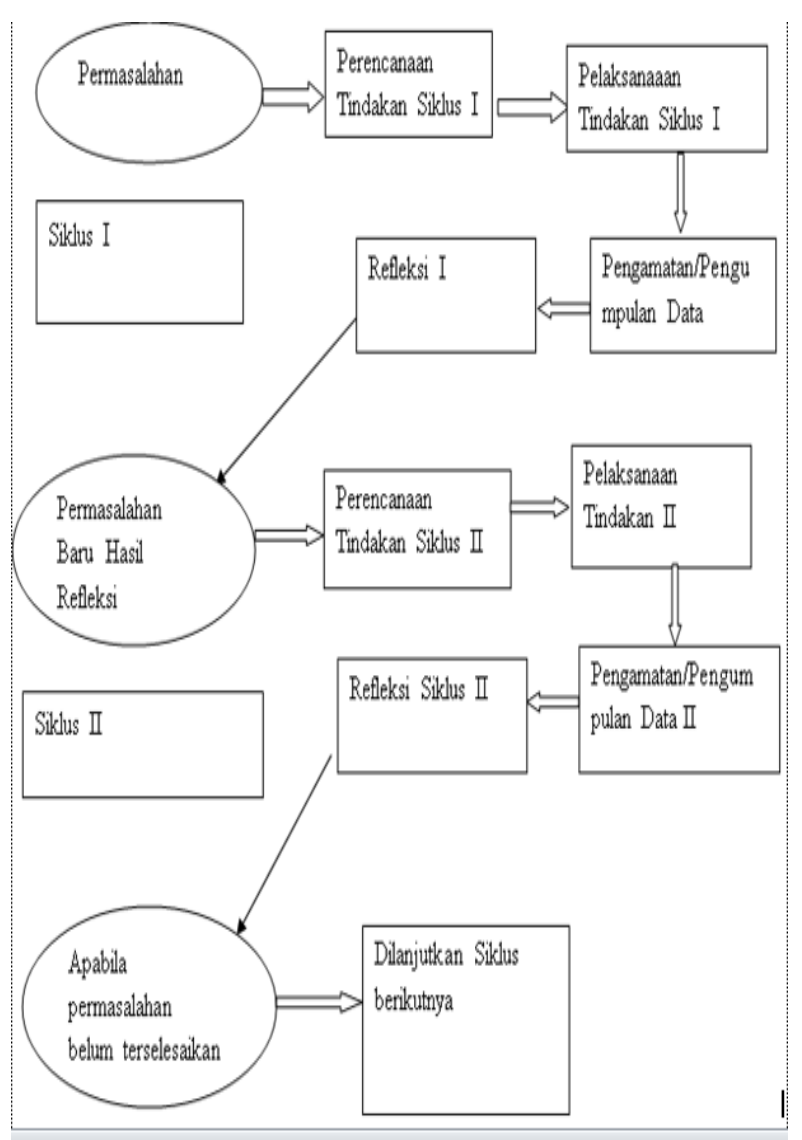

Gambar 1. Bagan Siklus Pembelajaran model Kemmis dan Mc Taggart

Pada tahap ini akan dianalisis data yang dikumpulkan baik pada saat pra kegiatan belajar, proses belajar, maupun sesudah sesudah proses belajar dilaksanakan. Adapun data yang perlu dia nalisis dalam PTK ini antara lain:

1. Aktivitas siswa dilakukan data hasil observasi secara deskriptif dengan teknik presentase:

$$
\mathrm{PK}=\frac{\text { jumlah Skor yang Diperoleh }}{\text { jumlah skor maksimal }} \times 100
$$

Kriteria yang digunakan dalam bentuk rentang skor yakni:

$$
\begin{aligned}
& 80-100 \%=A \\
& 70-79 \%=\mathrm{B} \\
& 45-59 \%=\mathrm{C} \\
& \leq 44 \%=\mathrm{E}
\end{aligned}
$$

2. Analisis data hasil dalam hal mengetahui kemampuan literasi sosial anak didik:

$$
\mathrm{RK}=\frac{\text { jumlah nil ai akhir posorta didik soluruhnya }}{\text { jumlah peserta didik keseluruhan }} \times 100 \%
$$

\section{HASIL DAN PEMBAHASAN}

Berlangsungnya pembelajaran dan aktivitas anak didik dalam belajar dengan menerapkan pembelajaran kooperatif picture and picture bermedia mind map ditulis hasil pengamatannya di dalam lembar pengamatan oleh observer. Observasi dilakukan selama proses mengajar berlangsung. Observasi yang dilaksanakan berpedoman pada lembar observasi yang sebelumnya telah disiapkan. Rentang skor yang digunakan adalah 1-5 dengan keterangan skornya adalah 1 = tidak baik, $2=$ kurang baik, $3=$ cukup baik, 4 = baik, 5 = sangat baik dan kriteria penilaian yang digunakan adalah $>20 \%=$ tidak baik, $20 \%-30 \%=$ kurang baik, $40 \%-59 \%=$ cukup baik, $60 \%-79 \%=$ baik dan $>80 \%=$ sangat baik.

Secara ringkas data keberlangsungan pembelajaran dan aktivitas anak didik selama belajar dengan menerapkan pembelajaran kooperatif picture and picture bermedia mind map dipaparkan pada tabel berikut ini. 
Tabel 1. Hasil Keterlaksanaan Pembelajaran Dan Aktivitas Peserta Didik Pada Siklus I Dan II

\begin{tabular}{|c|l|c|c|}
\hline$N_{0}$ & \multicolumn{2}{|c|}{ Instrumen } & \multicolumn{2}{|c|}{ Keterlaksanaan } \\
\cline { 3 - 4 } & & Siklus I & Siklus II \\
\hline 1. & Hasil Observasi Keterlaksanaan Pembelajaran & $78,3 \%$ & $95 \%$ \\
\hline 2. & Hasil Observasi Aktivitas Peserta Didik & $68 \%$ & $88 \%$ \\
\hline
\end{tabular}

Data keterlaksanaan pembelajaran dan aktivitas anak didik diperoleh dengan observasi selama pembelajaran berlangsung. Lembar observasi sebagai pedoman keterlaksanaan pembelajaran menggunakan kisi-kisi instrumen penelitian dengan variabel pembelajaran kooperatif picture and picture bermedia mind map dan sub-variabelnya kegiatan awal, kegiatan inti, dan kegiatan akhir. Setiap sub-variabelnya memiliki indikatornya masing-masing. Sedangkan untuk obsevasi aktivitas peserta dididk menggunakan sub-sub variabelnya antara lain, kognitif, afektif, psikomotorik. Setiap sub-variabel memiliki indikatornya masing-masing.

Berdasarkan tabel 1 diatas bahwa penilaian pengamat diperoleh nilai keterlaksanaan belajar tahap I 78,3\% dengan predikat baik dan tahap II 95\% dengan predikatsangat baik. Sedangkan aktivitas peserta didik pada siklus I $68 \%$ dengan kategori baik, dan siklus II $88 \%$ dengan kategori sangat baik, nilai yang diperoleh selalu meningkat di setiap siklusnya.

Diagram 1, terlihat keterlaksanaan pembelajaran dan aktivitas siswa selalu menunjukani peningkatan disetiap siklusnya.
Hingga dapat ditarik kesimpulan bahwa pembelajaran kooperatif picture and picture bermedia mind map dapat meningkatkan aktivitas keterlaksanaan pembelajaran dan aktivitas peserta didik telah mencapai indikator keberhasilan dan meningkat setiap silkusnya. Hal tersebut menunjukan bahwa keterlaksanaan pembelajaran dan aktivitas anak didik selama diterapkan model tersebut sudah baik.

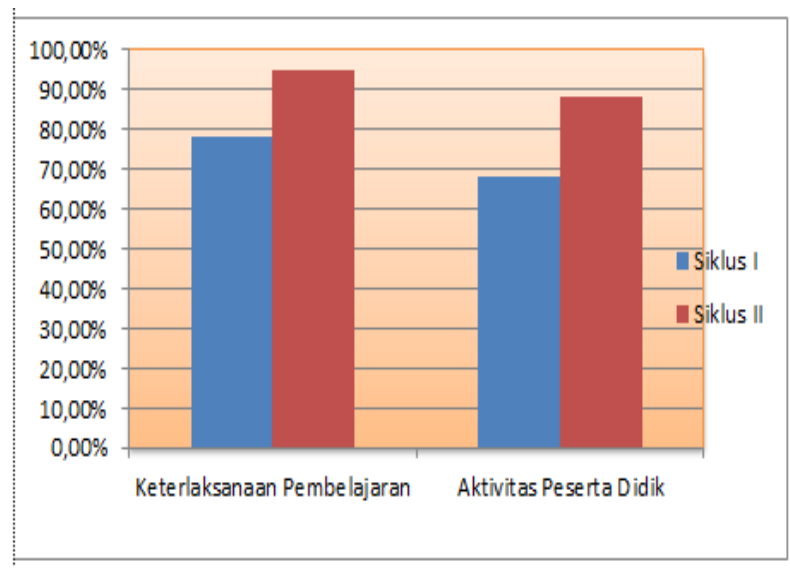

Diagram 1. Hasil Keterlaksanaan Pembelajaran dan Aktivitas Siswa Tahap I dan II

Untuk mengukur tingkat kemampuan literasi sosial yang diperoleh setiap anak didik, pada akhir pembelajaran peneliti memberikan soal tes atau evaluasi. Masing-masing peserta didik diberikan kesempatan menyelesaikan soal. Tujuan kegiatan evalusai untuk mengetahui seberapa peningkatan kemampuan literasi sosial yang diperoleh setiap peserta didik. Hasil tes siklus I terungkap bahwa dari 29 orang peserta didik kelas IV SDN Ende 1, ternyata hanya 19 orang yang mencapai batas Kriteria Ketuntasan Minimal. Sedangkan yang tidak mencapai (KKM) sebanyak 10 orang. Ini 
menunjukan bahwa keberhasilan peserta didik siklus I berada pada kategori Cukup. Sedangakan hasil tes evaluasi pada siklus II diketahui bahwa semua anak didik sudah memenuhi Kriteria Ketuntasan Minimal ketuntasan belajar anak didik mencapai $100 \%$, berada pada predikat sangat baik. Oleh karena itu pelaksanaan penelitian berakhir pada tahap II. Skor rata-rata hasil tes evaluasi anak didik pada tahap I dan II dapat dilihat pada tabel berikut ini:

Tabel 2. Hasil Tes Evaluasi Peserta Didik Pada Siklus I Dan II

\begin{tabular}{|c|c|c|}
\hline No & Siklus I & Siklus II \\
\hline 1 & $65,51 \%$ & $100 \%$ \\
\hline
\end{tabular}

Tabel diatas menandakan tes evaluasi belajar anak didik secara keseluruhan kegiatan I dengan nilai berjumlah $65,51 \%$ kriteria cukup baik. Sedangkan kegiatan II tes evaluasi belajar peserta secara menyeluruh skor $100 \%$ dengan kategori sangat baik dan sudah tercapai KKM yang ditentukan di sekolah. Tes evaluasi belajar anak tahap II dengan mengimplementasikan proses kooperatif picture and picture bermedia mind map. Secara ringkas tes evaluasi belajar siswa dapat dilihat pada diagram berikut:

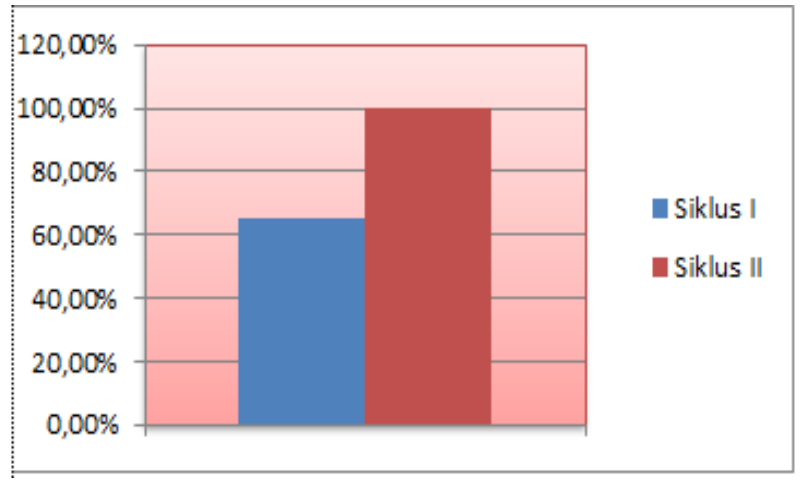

Diagram 2. Tes Evaluasi Belajar Peserta Didik Secara Klasikal Kegiatan I dan II

Berdasarkan gambar diatas, menunjukan peningkatan kemampuan literasi sosial siswa mulai kegiatan I dan II. Terlihat kegiatan I dengan ketuntasan $65,51 \%$ siklus II dengan ketuntasannya 100\%. Jadi, melalui penelitian yang telah dilaksanakan dengan menerapkan proses kooperatif picture and picture bermedia peta konsep terbukti dapat meningkatkan kecakapan literasi sosial peserta didik kelas IV yang hasil tesnya tuntas atau memenuhi KKM yang ditentukan.

Berdasarkan penjelasan pada bagian sebelumnya yang menyatakan bahwa implementasi pembelajaran kooperatif picture and picture bermedia peta konsep merupakan sebuah kegiatan belajar yang mendidik anak untuk berpikir kritis dan sistematis. (Hasyda, 2020) menyatakan siswa yang memiliki kemampuan berpikir menurut pandangnya sendiri sekaligus melatih bisa berargumentasi terhadap suatu prespektif gambar, dan menumbuhkan motivasi belajar siswa. Hal ini didukung dengan hasil observasi kegiatan siswa dan hasil pengamatan 
keterlaksanaan proses yang menunjukan adanya peningkatan yakni: aktivitas peserta didik kegiatan I berjumlah $68 \%$ pada predikat cukup, kegiatan II berjumlah $88 \%$ pada predikat sangat valid. Sedangkan hasil observasi keterlaksanaan pembelajaran putaran I 78,3\% dengan predikat baik dan putaran II 95\% dengan predikat sangat valid.

Adapun data-data analisis evaluasi siswa kelas IV SDN Ende 1 putaran I, sejumlah 19 orang siswa atau $65,51 \%$ memenuhi KKM sedangkan ada 10 orang siswa dan $34,48 \%$ yang belum memenuhi kriteria ketuntasan minimal dengan skor nilai adalah $65 \%$. Sedangkan tes penilaian putaran II terhadap siswa kelas IV SDN Ende 1 diketahui bahwa tidak ada siswa mendapatkan nilai dibawah Ukuran Ketuntasan Minimal. Semua siswa yang mendapatkan nilai $\leq 65$ sebanyak 29 orang atau $100 \%$ dengan rata-rata $86,55 \%$.

Bertolak dari uraian diatas dapat ditemukan dalam penerapan metode discovery pada peserta didik SDN Ende 1 mengalami peningkatan yang signifikan dari siklus sebelumnya. Penerapan pembelajaran kooperatif picture and picture bermedia peta konsep memiliki dampak positif terhadap peningkatan literasi sosial siswa terkhususnya mata pelajaran IPS. Hal ini dibuktikan hasil tes putaran I dan II. Begitu pula dari hasil pengamatan tercatat bahwa kgiatan siswa memperoleh skor $88 \%$ dan keterlaksanaan pembelajaran dari setiap siklus mencapai skor $95 \%$ dan akhirnya mencapai kategori sangat baik.

\section{SIMPULAN}

Berdasarkan rumusan masalah dan hasil penelitian yang telah dibahas, maka dapat ditarik kesimpulan bahwa pelaksanaan penelitian tindakan kelas dengan mengimplementasikan pembelajaran kooperatif picture and picture bermedia mind map pada mata pelajaran IPS pada peserta didik sekolah dasar dapat meningkatkan literasi sosial peserta didik. Hal ini dibuktikan dengan hasil observasi keterlaksanaan belajar tahap I mencapai 78,3\%. Ini menunjukan bahwa pencapaian keterlaksanaan pembelajaran berada pada kategori baik. Dan hasil observasi aktivitas peserta didik pada siklus I mencapai $68 \%$. Hal ini menunjukan bahwa tingkat pencapaian aktivitas peserta didik berada pada kategori cukup. Sedangkan evaluasi yang dilakukan pada tahap I maka diperoleh jumlah anak yang sudah mencapai KKM sebanyak 19 orang dan yang belum mencapai KKM sebanyak 10 orang, dan untuk nilai tertinggi adalah 80 dan nilai terendah 40. Dengan demikian tingkat pemahaman peserta didik terhadap materi yang disajikan dengan penerapan pembelajaran kooperatif picture and picture bermedia mind map berada pada kategori cukup. Sedangkan hasil observasi keterlaksanaan pembelajaran siklus II mencapai 95\%. Ini menunjukan bahwa pencapaian keterlaksanaan pembelajaran berada pada kategori sangat baik. Hasil observasi aktivitas peserta didik pada siklus II sudah mencapai $88 \%$. Sedangkan hasil tes evaluasi yang dilaksanakan pada siklus II semua peserta didik mencapai KKM yang ditetapkan di sekolah dengan rata-rata $100 \%$. Dengan demikian tingkat pemahaman peserta 
didik terhadap materi yang disajikan dengan menerapkan pembelajaran kooperatif berada pada kategori yang sangat baik. Hasil ini sejalan dengan penelitian (Andriani et al., 2019) yang mengemukakan bahwa model picture and picture efektif meningkatkan hasil belajar.

Sehubungan dengan hasil yang dicapai dalam penelitian ini, maka bagi guru, diharapkan dapat meningkatkan profesionalisme kinerja dalam mengelolah kegiatan pembelajaran dengan menerapkan pembelajaran kooperatif picture and picture bermedia mind map. (Daryanti \& Taufina, 2020) mengungkapkan belum terbiasanya guru dan siswa dalam model ini sehingga membutuhkan alokasi biaya yang cukup pada pengembangannya. Maka dari itu peran guru juga sangat penting dalam membimbing dan membina peserta didik secara induvidual sehingga anak didik berani memulai kegiatan belajarnya dan dapat lebih mengingat dalam jangka waktu yang lama untuk materi yang disampaikan. Lebih lanjut (Lamahala dkk.,2018) menyatakan bagi peserta didik, diharapkan dengan kawan lebih cenderung aktif dalam seluruh proses pembelajaran sehingga hasil belajarnya lebih baik lagi dari sebelumnya dan lebih berani lagi menemukakan ide atau gagasan baru untuk memperoleh hasil sesuai yang diharapkan.

\section{DAFTAR PUSTAKA}

Ananda, R., Rafida, T., \& Syahrum, S. (2015). Penelitian tindakan kelas. Citapustaka Media.
Andriani, D., Sulasmono, B. S., \& Setyaningtyas, E. W. (2019). Efektivitas Penerapan Model Pembelajaran Kooperatif Tipe Picture And Picture Dan Example Non Example Terhadap Hasil Belajar Pada Pembelajaran Tematik Kelas Iv Sdn Gugus Ki Hajar Dewantara. Jurnal Basicedu, 3(2), 553-558.

Darmastuti, H. (2014). Manajemen Sarana dan Prasarana dalam Upaya Peningkatan Kualitas Pembelajaran pada Jurusan Teknik Komputer dan Informatika di SMK Negeri 2 Surabaya. Inspirasi Manajemen Pendidikan, 3(3).

Daryanti, D., \& Taufina, T. (2020). Penggunaan Media Pembelajaran dalam Model Picture and Picture untuk meningkatkan Hasil Belajar Siswa. Jurnal Basicedu, 4(2), 484490.

Devi, R. S., Yuliariatiningsih, M. S., \& Mulyati, T. (2015). Efektivitas Metode Mind Mapping Terhadap Peningkatan Pemahaman Konsep Siswa Pada Mata Pelajaran IPA. Jurnal PGSD Kampus Cibiru, 3(2).

Gunawan, R. (2011). Pendidikan IPS filosofi, konsep dan aplikasi. Bandung: Alfabeta.

Hasyda, S. (2020). Penerapan Metode Pembelajaran Discovery dalam Meningkatkan Prestasi Belajar IPA Pada Peserta Didik Kelas IV di Sekolah Dasar. Jurnal Pendidikan Dasar Flobamorata, 1(1), 6-13.

Huda, M. (2011). Cooperative Learning metode, teknik, struktur dan model penerapan. Yogyakarta: Pustaka Pelajar.

Lamahala, M. H., Lamen, S., \& Uslan, U. (2018). Pengembangan Media Jaringan Epidermis Tanaman Jagung (Zea Mays L.) Yang Tumbuh Di Kota Kupang Sebagai Sumber Belajar Tambahan Pembelajaran IPA SD Berbasis Kearifan Lokal. Jurnal Ilmiah Pendidikan Citra Bakti, 5(2), 15-25. 
706 Penerapan Pembelajaran Kooperatif Picture And Picture Bermedia Mind Map Untuk Meningkatkan Kemampuan Literasi Sosial Pada Peserta Didik Kelas IV di Sekolah Dasar - Suryadin Hasyda, Arifin Djenawa

DOI: $10.31004 /$ basicedu.v4i3.414

Rusman, M. P. (2012). Mengembangkan Profesional Guru, Jakarta: PT. Raja Grafindo Persada.

Sanjaya, W. (2006). Strategi pembelajaran berorientasi standar proses pendidikan.

Slavin, R. E. (2005). Cooperative learning teori, riset dan praktik. Bandung: Nusa Media, 236.

Suprijono, A. (2009). Cooperative learning: Teori \& aplikasi PAIKEM. Pustaka Pelajar. 